\title{
Parliament-government-citizens. The place of the institution of direct democracy in the discussion on the shape of San Marino-European Union relations in the context of the referendum of $2013^{1}$
}

\begin{abstract}
Abstrakt: The subject of the article is the issue of using the institutions of direct democracy in the process of shaping the directions of a very specific element of foreign policy - relations with the European Union, of which San Marino is not a member. While most of the referenda related to the European Union concern the accession of countries to this organization, the vote in 2013 was of a slightly different nature. Therefore, the author attempts to indicate how the use of the instruments of direct democracy by citizens, in a way in opposition to the institution of indirect democracy (parliament and its dependent government), can contribute to the decision-makers making political decisions desired by citizens, even in seemingly rather unusual (apart from the aforementioned accession referenda) for direct democracy, spheres as the directions of foreign policy.
\end{abstract}

Key words: referendum, San Marino, European integration

$\mathbf{S}$ an Marino $^{2}$ is one of several Western European countries that remains outside the structures of the European Union. Nevertheless, of the three Western European countries with a small territory (Vatican, Monaco and San Marino), it seems to be pursuing a pro-integration policy in the most advanced way. While the question of the fate of relations between the European Union and the three microstates (Andorran, Monaco and San Marino) is currently the subject of negotiations with the short-term aim of concluding an association agreement, it was only in the case of San Marino that the decision on relations with the Union was taken using the institution of direct democracy, which is a referendum, and this decision has had a significant impact on the current shape of relations between the EU and San Marino. Proving this hypothesis will be the primary objective of this article.

Both the political system and the issue of bilateral relations between the European Union (hereinafter: the EU) and San Marino is a fairly broad issue, which is why it should be noted at the outset that the author's goal is not a comprehensive look at these relations, but only to focus on the issue of the Sammarinese citizens using the institutions of direct democracy in shaping their country's relations with the European Union. In order to achieve this goal, it will be necessary to analyze the statements of politicians and official positions of the party, supplemented by a historical outline of bilateral relations between

${ }^{1}$ The article was written as part of a project co-founded by the Erasmus+ Programme of the European Union "Jean Monnet Center of Excellence EU EX/ACT-EU External Actions in the contested global order - (in)coherence, (dis)continuity, resilience".

DISCLAIMER: The European Commission support for the production of this publication does not constitute an endorsement of the contents which reflects the views only of the authors, and the Commission cannot be held responsible for any use which may be made of the information contained therein.

${ }^{2}$ Further for stylistic purposes also as the Republic of San Marino or the Republic. 
the EU and San Marino. The goal set seems interesting because in the case of both Andorra and Monaco, citizens have not yet used any institutions of direct democracy to influence decisions on their countries' relations with the European Union by, for example, encouraging the government to be more active. The reasons for the lack of such activity in those countries should be the subject of a separate study, although in the case of Monaco the answer to the question posed seems quite simple: this constitution, as one of the few basic laws on our continent, does not provide for any form of direct democracy.

\section{Establishing cooperation (historical outline of the relationship)}

Relations between San Marino and the European Union (then the European Community) were established only in 1983, despite the fact that Italy, San Marino's only neighbor, was the founding country of the European Communities. Despite the late establishment of relations, it should be pointed out that, in relation to other microstates, San Marino was one of the first to undertake measures aimed at rapprochement with the European Community. This could, inter alia, be due to the unfavorable status of the Sammarinese economy: San Marino is an enclave on the territory of Italy. In 1968, a customs union was established within the Framework of the European Economic Community, outside which the Republic formally found itself, although San Marino was treated as part of this union. A huge change in this matter was brought about by the signing of the cooperation agreement and the customs union at the end of 1991.

The signed agreement was not the only one that formed the basis for the European Union's subsequent cooperation with the Republic, because in the same year San Marino concluded a convention with its neighbor that was to regulate the issue of minting coins. This foundation, together with the institutionalization of the idea of monetary and monetary union, allowed for the subsequent designation of the Italians as responsible on the part of the Union for negotiating the appropriate monetary convention, which was to regulate EU-San Marino relations in this area.

Finally, it was agreed that San Marino would have the right to decide on the appearance of the reverses of the euro issued in the Republic. The Convention was signed in 2000 and the Italian-Sammarinese Convention of 1991 thus ceased to be valid. Without going into too many details of the provisions of the Convention, it is worth mentioning that on 1 January 2002 the euro became San Marino's legal tender and its authorities were obliged to fight currency counterfeiting. The Convention was amended in 2012 and the rules on euro emission limits were slightly loosened. ${ }^{3}$

\section{European integration in San Marino's internal policy}

The European Union, as an organization constituting a possible point of reference, has not been an important element of the discussion of Sammarinese politicians for many

${ }^{3}$ It is worth adding that years later, the government of the Republic was obliged to implement appropriate legal regulations (EU regulations), the purpose of which was to combat fraud and falsification of means of payment and money laundering. 
years. Close relations with Italy seemed to fill a significant part of the interest of the politicians of the Republic. While in the early 90s and for the next decade, despite closer cooperation with the EC/EU, the issue of European integration was not a subject of greater interest for Sammarinese, the second decade of the twenty-first century, including through the tools of direct democracy used more and more often, has become a period of significant change. This was followed by the use of these tools to address foreign policy issues aimed at European integration.

In February 2003, a proposal was made to organize a referendum on the future of relations between San Marino and the European Union. The Sammarinese were to answer the question whether they agreed to the parliament giving a negotiating mandate to the government "in order to initiate the formalities necessary for the implementation of the Memorandum of Understanding with the European Union, including the membership of the Republic of San Marino in the Union after the approval referendum?" In the end, the vote did not take place due to the decision of the Judicial Council (Collegio Giudicante) ${ }^{4}$ (Decreto, 2003).

At the end of 2010, the initiative from seven years ago was repeated, but its fate was similar: the referendum also did not take place. While this time the Sammarinese constitutional court ${ }^{5}$ declared the referendum legally admissible, and the head of state (Captains-Regents) set the date of the vote for March 27, 2011. However, due to the initiative taking place simultaneously in parliament (about it below), which was supposed to fulfill the demands of the initiators, almost exactly a month before the vote, the referendum was cancelled.

At the beginning of 2010, a new unit was established - the so-called technical group whose task was to ${ }^{6}$ analyze the directions of policies that could be implemented in relations with the European Union. Already in December of the same year, following a report prepared by this unit (Rapporto, 2010), a group of parliamentarians called on the government of the Republic to start negotiations with EU decision-makers on greater integration of their country with the Union and to assess the existence of political and international conditions necessary to start negotiations on the accession of the Republic to this organization. Parliamentarians pointed out that the 1991 agreement made it possible to establish fruitful relations with the Community, but the time has come to deepen integration. Already in the first sentences of the document adopted at the session of the parliament, it was noted that the negotiations must take into account the possibilities of achieving by San Marino "in the shortest possible time the objectives considered necessary for the growth and development of the state system, as well as the need to obtain exceptions that will allow the Republic to preserve the essential features of its identity" (Ordine, 2010). Thus, it should be noted that already then they were aware of the risk that membership in this organization becomes, in particular for smaller countries joining the European Union. As a result of the decision taken at that time, the government was authorized to start negotiations in order to deepen cooperation with the EU (Ordine, 2010).

${ }^{4}$ It was a quasi-constitutional court, one of whose powers was to exercise control over the admissibility of the organization of e.g. referendums.

${ }^{5}$ As a result of the constitutional reform, the legal admissibility of referenda was no longer the responsibility of the Judicial Council, but a new body - the College of Guarantee (in English also as the Guarantors' Panel on the Constitutionality of Rules - Collegio garante della costituzionalità delle norme).

${ }^{6}$ Technical Group for the evaluation of new ways of integration with the European Union. 
A direct result of these actions of the parliament was a request to the President of the European Council submitted on 20th January 2011 by the Sammarinese Secretary of State for Foreign Relations through diplomatic channels, as a result of which they wanted to bring about "greater and better European integration, including the possibility of applying for membership" (San Marino: richiesta, 2011).

In addition to the referendum attempts, it is also worth mentioning here other ways of influencing the government of San Marino in order to accelerate the process of bringing the Republic closer to the European Union. Such attempts were petitions submitted by citizens in the form of the so-called Istanza d'Arengo. This institution largely boils down to the possibility of submitting a special petition application to the newly sworn head of state by each citizen, which is obligatorily presented to parliamentarians by the head of state if the formal requirements are met (Lukaszewski, 2019, p. 122 and the following). ${ }^{7}$ Through it, citizens expressed their support for the idea of integration. For example, on 3 April 2011, Patrizia Busignani asked the Captains-Regents to submit to Parliament a request for the Government of the Republic to submit a formal application for membership of the European Union, but after the petition was admitted to parliament, the majority of its members voted against this solution (Istanza d'Arengo n.4, 2011). With regard to the institution of the Istanza d'Arengo, it is worth mentioning that eight years later another application was submitted. This time, the applicant demanded a referendum on membership of the European Union. ${ }^{8}$ However, this request was rejected as inadmissible due to the possibility of submitting the same proposal under the referendum initiative procedure (Istanza d'Arengo, n. 25, 2019). The use of the instruments of direct democracy was later used again - in 2013, when there was a referendum on the regulation of the Republic's relations with the European Union. About it later in the article.

Drawing attention to the attitude of Sammarinese politicians, it is worth emphasizing that parliamentarians largely supported the government's actions against the policy of gradual integration. In mid-2011, the parliament adopted by a clear majority further documents expressing the government's support and encouraging it to take further steps towards greater integration with the European Union. ${ }^{9}$ A few weeks later, the European Commission received an official announcement on the creation of a special cooperation committee, the establishment of which was due both to the need to agree on matters arising from the application of the customs agreement concluded earlier, but also to the willingness of the Sammarinese authorities to discuss further bilateral relations. Before the official meeting of the committee members in October, a month before, Secretary Antonella Mularoni once again went to Brussels, who met with the President of the European Council. Herman Van Rompuy welcomed the attitude of the Sammarinese political parties, as well as the actions of the parliament and government of that country.

${ }^{7}$ Leaving aside the question of the construction of the institution itself, which for obvious reasons cannot be the subject of this article, it seems necessary to state that while the status of this institution is not entirely easy to classify and include in the instruments of direct democracy, the equating it with the institution of petition that occurs in many other democratic countries does not find acceptance in the writer of these words.

${ }^{8}$ Originally in the application: "in the European Economic Community" (sic!) - for a referendum to be held for entry into the European Economic Community.

9 One of the documents was even adopted unanimously, which in the conditions of Sammarinese parliamentarism should be considered an unusual event (Ordine, 2011). 
A statement issued by the President of the European Council stressed that further cooperation between the EU and Sammarinese institutions would continue to a similar extent as it did for the Andorran and Monegasque institutions (Statement, 2011).

The events of early 2011 accelerated the activities of the government supported by the parliament, as a result of which, a few months later, in December, work was completed on the new structure of the Republic's public administration, which included the new structure of the Department of Foreign Affairs within the Sammarinese government. The department was divided into 5 directorates. One of them was the Directorate of European Affairs, whose main task has been to make relations and negotiation processes with the European Union. ${ }^{10}$ The Directory began its activity immediately, on January 1.

In March 2012, a meeting of technical groups from three microstates (in addition to the host also Andorra and Monaco) was held in San Marino. ${ }^{11}$ In July, Antonella Mularoni renewed her visit to Brussels. This time she met with the President of the European Commission, J. M. Barroso (San Marino -Unione). Barroso drew attention to the progress in the development of efforts of all three microstates towards greater integration with the Union. Throughout 2012, many other meetings were held at which the issue of further deepening cooperation was discussed - mainly in the formula of representatives of three microstates in representatives of the European Union.

In December 2012, the Council of the EU adopted conclusions that took stock of the EU-microstate cooperation to date, while pointing out two scenarios for the further evolution of these relations. These scenarios were association agreements (or one framework for all three microstates) and the participation of microstates in the European Economic Area. At the end of February 2013, the Sammarinese government was mandated by parliament to take action in line with the guidelines of the December 2012 conclusions by adopting a concrete action plan against the integration of the Republic into the EU through the adoption of Community legislation and reporting to parliament on a monthly report to the implementation of the measures taken (Ordine del Giorno, 2013).

The document adopted by the Council of the EU in December 2012 obliged the EU institutions to take action to determine the administrative capacity of microstates to adapt to the requirements provided for in the document. This was particularly important in the context of the unique nature of these countries, as their small population potential could entail possible administrative difficulties (too few human resources of state services), which would have a negative impact on the efficient implementation of solutions required by the EU side. As a result, already in March 2013, the EU delegation visited San Marino, the aim of which was to learn about the administrative capabilities of the Republic and to meet with representatives of the state administration responsible for the implementation of the acquis communautaire and adapting Sammarinese law to

${ }^{10}$ The Act enumerated 6 functions of the Directorate: (a) supervising and directing negotiations with the EU; (b) coordinating the negotiating position between public administrations on the possible adoption of the acquis communautaire; (c) coordinating and implementing procedures and obligations arising from commitments arising from commitments arising from negotiations with the EU; (d) to act as liaison with the other institutions of the Department of Foreign Affairs on political and economic issues relevant to the European context; (e) coordinating the preparation of relevant documents and legal acts; (f) ensuring that all other activities and tasks required by law are carried out (Legge, 2011, Annex A, Article 5).

11 The next one took place in September and it was hosted by Andorra. 
the rules prevailing in the EU. The following months meant numerous meetings for the Sammarinese secretary of state responsible for foreign affairs: with the Commissioner for Taxation and Customs Union, Audit and Anti-Fraud (June), the Foreign Ministers of the other two microstates (July), the President of the European Parliament (August) (San Marino. Valentini). At the end of the year, the EU institutions published their documents summarizing the efforts of the authorities of microstates to integrate more deeply with the EU: in November, the relevant document was adopted by the European Commission, and almost exactly a month later by the Council of the EU. The latter thus led to the choice of the scenario of the association agreement (or 3 agreements) as the future form of arranging relations between microstates and the European Union.

\section{Referendum}

As mentioned earlier, the Sammarinese used the tools of the political system (Istanza d'Arengo) to support the government's actions in policies aimed at greater integration of the Republic with the EU. One of such actions was also a referendum initiative, which was to result in support for the government in their efforts to strengthen relations with the EU. At the same time, it should be noted here that the planned vote for some meant at least a pre-accession referendum, and for others only support for the government as to the policy of deepening integration (a vote "no" in such a vote could then be perceived as a will to suspend this process, at most).

As mentioned earlier, the vote on EU-San Marino relations was not to be the first such in the history of the Republic, as in 2003 a similar initiative appeared (stopped by the court), which was renewed at the end of 2010 (with a vote scheduled for the end of March of the following year) with similar results. In view of the author of this article, it would be reasonable to invoke the proverb "third time lucky," because it was the initiative of 2012 that led to the effective act of voting. In June 2012, the initiators managed to collect over 500 signatures for a referendum motion, but due to the lack of a stable majority in parliament, the head of state ordered early elections a few weeks later, which legally interrupted the referendum procedure. This was initiated only after the elections, and the date of the referendum vote was set for October 20, 2013.

Citizens were to express their opinion on the issue of support for the pro-European direction adopted a few days earlier by the authorities of San Marino. However, what is worth emphasizing, the question that was put to the vote was long and repeatedly submitted, which could be perceived by citizens as confusing, and this in turn could cause doubts as to what de facto means voting "for" and "against," i.e. whether it means only a form of support for the government's actions for the process of integration of the Republic with the European Union, is a kind of quasi-accession referendum or merely a form of expression of support for the deepening of EU-San Marino relations. ${ }^{12}$

12 The wording of the question was as follows (own translation): 'The Republic shall promote the integration, economic, cultural and social policies of the population residing in its own territory in the European Union, shall share the principles and objectives of the Treaty establishing the Union and shall endeavour to acquire citizenship of the Union for its citizens. The Republic, assessing its own solutions to ensure compliance with the requirements set out in the Treaty on European Union, has started the 
San Marino's constitutional system distinguishes three types of referendums: abrogative referendum (referendum abrogativo), confirmative referendum (referendum confermativo) and propositive referendum (referendum propositivo o di indirizzo). The adoption of the proposal in the first two types of referendums is the final stage in the implementation of a political decision, while in the third case it is one of the first phases of the process. The effect of the first is the repeal of a legal act (or even a norm), the second - the approval of a proposal (e.g. a law), while in the case of the third, the adoption of a proposal being the subject of a vote obliges the government to submit to the head of state within 6 months a bill that is to solve the issue constituting the problem posed in the vote (Lukaszewski, 2018, p. 130). Then the head of state sends such a bill to the constitutional court, which decides whether the bill is in accordance with the will of the referendum motion voted by the majority of citizens. This bill is then referred to the parliament. It was this third type of referendum that was used to vote on October 20, 2013.

Almost $60 \%$ of Sammarinese living in the Republic took part in the voting. What is important for the result, citizens of the Republic living abroad almost completely boycotted the vote (turnout in this case was only 5.31\%), which ultimately affected the turnout level of $43.39 \%$. In the end, the votes of supporters and opponents of integration were divided almost equally: $6732(50.28 \%)$ were in favor, while the opposite opinion was held by 6657 voters $(49.72 \%)$, ${ }^{13}$ i.e. 75 citizens less. Almost 900 votes were cast in the form supported by the Christian Democrats (blank card). Another nearly 200 votes were invalid. Despite the fact that a small majority of voters voted in favor of the referendum motion, the referendum was not binding. According to the law of the time, a vote could be valid if the voters in favor of the referendum motion (apart from obtaining a majority) were at least $32 \%$ of all those entitled to vote, while the number of people voting 'for' in the referendum in question was only slightly over $20 \%$.

Table 1

Recommendations of the political groups taking part in the 2012 parliamentary elections regarding the vote in the $\mathbf{2 0 1 3}$ referendum on relations with the European Union

\begin{tabular}{|c|l|c|c||}
\hline & \multicolumn{1}{|c|}{ Political groups } & $\begin{array}{c}\text { Number of } \\
\text { deputies after } \\
\text { the elections }\end{array}$ & Recommendation \\
\hline 1 & \multicolumn{1}{|c|}{$\mathbf{2}$} & $\mathbf{3}$ & $\mathbf{4}$ \\
\hline \multirow{3}{*}{$\begin{array}{l}\text { Govern- } \\
\text { ment groups }\end{array}$} & Sammarine Christian Democratic Party & 21 & Blank ballots \\
\cline { 2 - 4 } & We Sammarinees 1 ) & 0 & Against \\
\cline { 2 - 4 } & People's Alliance & 4 & Decision left to voters \\
\cline { 2 - 4 } & Party of Socialists and Democrats & 10 & For \\
\hline
\end{tabular}

procedure for applying for membership of the European Union. The Government, in the name and on behalf of the Republic, is obliged to comply with the formal requirements for examination and negotiation provided for by the Treaty on Union, in order to ensure effectiveness within a relatively short period after the completion of the above accession procedure. The law will have to set a very short time frame in which the application for accession will have to be sent. The accession of the Republic to the European Union will be finalised only by a decision of the citizens expressed in a referendum approving on the initiative of a Member in accordance with Article 29 of Act No 101 of 28 November 1994. Do you want a law to be adopted containing the principles and criteria mentioned above?

${ }^{13}$ For discrepancies in the official figures, see the commentary on Table 2. 


\begin{tabular}{|l|l|c|c|}
\hline \multicolumn{1}{|c|}{$\mathbf{2}$} & $\mathbf{3}$ & $\mathbf{4}$ \\
\hline \multirow{4}{*}{$\begin{array}{l}\text { Opposition } \\
\text { groups }\end{array}$} & RETE Movement & 4 & Against \\
\cline { 2 - 4 } & Socialist Party & 7 & For \\
\cline { 2 - 4 } & Union for the Republic & 5 & For \\
\cline { 2 - 4 } & United Left & 5 & For \\
\cline { 2 - 4 } & Civic10 & 4 & For \\
\hline \multirow{2}{*}{$\begin{array}{l}\text { Non-par- } \\
\text { liamentary } \\
\text { opposition }\end{array}$} & Unione Sammarinese dei Moderati & 0 & $\begin{array}{c}\text { The party dissolved after the } \\
\text { electoral defeat in 2012. }\end{array}$ \\
\cline { 2 - 4 } & San Marino 3.0 & 0 & Against ${ }^{2}$ \\
\cline { 2 - 4 } & For San Marino & 0 & For \\
\hline
\end{tabular}

Source: Own study based on many sources, incl. D. M. De Luca, $A$ San Marino si vota per entrare nell'Uniane Europea, 20.10.2013, Il Post, https://www.ilpost.it/2013/10/20/referendum-san-marino-unione-europea/, 13/08.2021; Local democracy in the Republic of San Marino, Council of Europe, https://rm.coe.int/local-democracy-in-san-marino-en-monitoring-committee-rapporteurs-gunn/16807a8d25, 09/06/2021; Tutte le for politiche si sono schierate circa il referendum sull'Europa, SMTV San Marino, http://www.smtvsanmarino. sm/politica/2013/09/19/tutte-forze-politiche-si-sono-schierate-circa- referendum-sull-europe, 06/09/2021; Europe Referendum: Ap non dà indicazioni di voto, SMTV San Marino, http://www.smtvsanmarino.sm/ politica/2013/09/24/referendum-europa-ap-non-indicazioni-voto; 09/06/2021; Europe: Noi Sammarinesi ribadisce il suo NO ad un percorso di piena adesione, SMTV San Marino, http://www.smtvsanmarino.sm/ politica/2013/08/30/europa-noi-sammarinesi-ribadisce-suo-no-percorso-piena-adesione, 06/09/2021; San Marino. Per San Marino invita a votare si per aprire una trattativa con la UE, Giornale San Marino, https:// giornalesm.com/san-marino-per-san-marino-invita-a-votare-si-per-aprire-una-trattativa-con-la-ue-58866/, 09/06/2021.

1) the group We Sammarineses appeared together with the Christian Democrats. Both groups are listed separately in the table for better readability;

2) no data. San Marino 3.0 is a Eurosceptic party and, after the vote, expressed its joy at the outcome. San Marino 3.0. Ok referendum Europe! Ora la prima cosa da fare è cacciare la Dirigenza di Banca Centrale!, Giornale San Marino, https://giornalesm.com/san-marino-3-0-ok-referendum-europa-ora-la-prima-cosa-da-fare-e-cacciare-la-dirigenza-di-banca-centrale-19293/, 09.09.2021.

The result of the vote was, of course, commented on by representatives of individual groups. Some of the groups pointed to the legitimacy of abolishing the "quorum" requirement ${ }^{14}(32 \%)$, whose stay in the political system meant that supporters of the referendum initiative had to convince not only active (i.e. voting) citizens, but also those who decided not to participate in the vote. The amendment to the law regulating the referendum, which was passed a few weeks earlier, was supposed to abolish it, but parliamentarians finally decided only to reduce it to $25 \%$, with the provision that it will not apply to the next referendum (i.e. the one being the subject of this article). As it turned out later, the very requirement to obtain a "quorum" for the validity of a decision taken in a vote, in 2016 in a referendum was abolished. ${ }^{15}$

${ }^{14}$ The quotation marks used here and later are due to the fact that the requirement was not to obtain a quorum understood as a certain number of voters, but the number of voters "for" in relation to the total number of eligible voters.

15 With regard to this vote, the ratio of "for" the repeal of the need to obtain a "quorum" to the number of eligible voters was $27.3 \%$, and therefore slightly exceeded the required threshold $(25 \%)$. 
Results of the referendum of 20 October 2013 on relations with the European Union

\begin{tabular}{|c|c|c|c|c|c|c|}
\hline \multirow{3}{*}{ Number of eligible voters } & \multicolumn{3}{|c|}{ Elezioni.sm* } & \multicolumn{3}{|c|}{ Referendum.sm* } \\
\hline & \multicolumn{3}{|c|}{33,303} & \multicolumn{3}{|c|}{33,303} \\
\hline & I & $\mathbf{E}$ & $\mathbf{R}$ & I & $\mathbf{E}$ & $\mathbf{R}$ \\
\hline Number of voters & - & - & 14,448 & - & - & 14,455 \\
\hline Number of valid votes & 12,832 & 557 & 13,389 & 12,833 & 557 & 13,390 \\
\hline Number of empty votes (blank card) & 840 & 27 & 867 & 824 & 27 & 851 \\
\hline Number of invalid votes & 177 & 15 & 192 & 193 & 15 & 208 \\
\hline Number of votes for „YES” & 6,388 & 344 & 6,732 & 6,389 & 344 & 6,733 \\
\hline Number of votes for „NO” & 6,444 & 213 & 6,657 & 6,444 & 213 & 6,657 \\
\hline
\end{tabular}

I - the voices of the Sammarinese living in the territory of the Republic; E - residing outside the territory; $\mathrm{R}$ - together.

* - The numbers in the table above vary slightly depending on the government source (sic!). Both websites (elezioni.sm and referendum.sm) are the pages of the Secretariat of State for Home Affairs devoted to elections and/or referendums.

Source: own study based on these sources.

Extra-parliamentary grouping - San Marino 3.0 expressed its joy at stopping the process of "selling the sovereignty of San Marino to Brussels" (San Marino 3.0. Ok referendum). The RETE movement stressed that the majority of voters were ultimately against integration, emphasizing the role of blank ballots (which were de facto votes against) (San Marino. Flop). In turn, the Social Democrats supporting the "for" vote stressed that in their opinion the votes of non-voters cannot be equated with those who went to the polling stations, but voted "against." They drew attention to the very unsatisfactory participation of Sammarinese living abroad, pointing to the need to change the electoral law in order to facilitate their participation in the political life of the Republic. ${ }^{16}$ We Sammarinese (the only party within the government coalition calling for a 'no' vote) stressed that the main motivation behind the recommendation to reject the referendum initiative was: a wrong question, at the wrong time and with a proposal to improperly implement the referendum initiative, and the result of the vote could not be read as a vote against Europe (Referendum, Noi Sammarinesi). For San Marino perceived the result of the vote as a defeat of the government, in which there was a clear conflict over a single-sounding recommendation to the voters. In a statement of the For San Marino, there was a malicious statement that "three and a half parties [included in the government coalition - M.Ł.] stood in 4 different positions" (Per San Marino). In turn, politicians of the opposition Union for the Republic (UPR) pointed out that the fact that parliamentarians maintained the requirement to obtain a "quorum" for the October 2013 vote (which the UPR was against) was in their opinion really aimed at bringing down the referendum motion on European integration (San Marino. Affondato; Trad: risultato). The Christian Democrats (PDCS), who had the largest number of seats, read the result of the referendum as the vote of Sammarinese against membership in the European Union, but support for the idea of a looser binding of the Republic with the Union - the association agreement $(I l P d c s)$. In a similar way, the Secretary of State Pasquale Valentini, responsible for foreign affairs, spoke on behalf of the government, indicating that the result of

\footnotetext{
${ }^{16}$ More on the reaction of politicians after the referendum: (San Marino Oggi; Rete qualche).
} 
the referendum should be read as a desire to get closer to the European Union, but not through membership in its structures, but their own way, which will take into account the specifics of their situation. The above narrative of the individual parliamentary groups and the government was largely later transferred to the parliamentary field, where during the debate the issues of both interpretation and possible further political decisions that must be taken were discussed (Consiglio: dibattito).

The result seemed to call into question the future of the EU's relations with the Republic (Guicciardi), but ultimately these concerns may have been largely due to difficulties in interpreting the will of the Sammarinese themselves. A clear "no" vote would show that they are against closer integration, an equally clear "yes" vote would mean a strong vote of citizens in favour of taking a strong course towards membership of the European Union. In the end, however, the almost equal number of "yes" and "no" votes combined with low turnout introduced some anxiety about how to interpret the result of the referendum. It seems that the government's decision to interpret it based on the choice of an intermediate solution (and therefore an association agreement) was the only possible one. The legitimacy of such a choice will come to write only a few years after its implementation.

\section{Summary}

More than a year after the referendum, in December 2014 the Council of the EU gave its consent for the Commission to start negotiations on an agreement or association agreements with three microstates. 4 years later, the Council of the EU adopted conclusions in which it presented the state of the EU's relations m.in with 3 microstates (but also with Iceland). The efforts of microstate governments to adapt tax regulations and practices to EU and international standards were highlighted. On 4th December 2018 the EU Economic and Financial Affairs Council (ECOFIN) took note of the progress made by Andorra and San Marino. At the beginning of 2019, the European Parliament's Committee on Foreign Affairs (AFET) prepared a report to the Council, the European Commission and the High Representative of the Union for Foreign Affairs and Security Policy and a corresponding draft recommendation of the European Parliament. The Commitee (AFET) advocated such institutional and political support for microstates from the European Commission that negotiations on the association agreement could be concluded no later than within the next two years.

Referendums are currently one of the institutions of direct democracy, which to a large extent is to solve ideological issues (abortion in Ireland in 2018; admissibility of divorce in Malta in 2011; same-sex marriage in Ireland in 2015 (more: Kużelewska, 2019, pp. 13-27)), but also issues of great importance for the community, which is undoubtedly the country's accession to the EU, which decisions in a significant number of the current EU member states were taken precisely by referendum (Musiał-Karg, 2017, pp. 225-240). ${ }^{17}$ Finally, the

17 The accession referendum has become such a popular institution that it has become a kind of norm, as a result of which - as A. Parol notes - after the entry into force of the Single European Act, only Cyprus and Bulgaria have limited themselves to ratifying the agreement as part of parliamentary procedures (Parol, 2021, p. 39 and 42). 
referendum itself was a repeatedly used instrument for deciding on European policy ${ }^{18}$ after a country's accession (so-called revision referendums) (Parol, 2021, p. 42). However, referendums on European policy long before a country's possible accession are undoubtedly a rather peculiar case. ${ }^{19}$ This was the nature of the 2013 vote.

Analyzing the behavior of political decision-makers in the Republic, the relatively slow, but at the same time quite clearly maintained course of political actions, the aim of which was to bring closer to the EU structures, is striking. This course has not been abandoned to a large extent by any subsequent government, despite the fact that the Sammarinese party system is characterized by quite high instability, ${ }^{20}$ and even within the government itself was often possible to see mutually contradictory views, which was perfectly illustrated by the recommendations of coalition political parties regarding the 2013 vote. Hence, it is a truism worth emphasizing, however, that the aforementioned direction had different goals in its assumption: for some it was membership in the Union, and for others only a rapprochement ended with a bilateral agreement. The significance of the 2013 referendum should not obscure other initiatives using the institution of Istanza d'Arengo, through which citizens wanted to support (or perhaps strengthen) the government's efforts it means greater integration of the Republic into the Union. In the end, it was the efforts of both citizens and the members themselves supported by these initiatives that led to the 2013 vote.

The hypothesis put forward in the introduction seems to be confirmed, because it was - however perverse it may sound - that the ambiguous decision of the Sammarinese in the vote gave the government an impulse to more clearly define the course of their country's relations with the European Union. However, the minimal victory of the "for" option over the "against" option, combined with a low turnout, gave an impulse to move away from the idea of possible membership, which was previously one of the possibilities. In other words, the referendum limited the formula of a wide range of scenarios for the development of relations with the Union ('from a slight approximation to membership inclusive') to rapprochement in the form of the conclusion of an association agreement with the Union.

\section{Bibliography}

Agreement on Cooperation and Customs Union between the European Economic Community and the Republic of San Marino - Declarations Official Journal L 084 (2002), 22002A0328(01), 28.03.2002, P. 0043-0052.

Consiglio: dibattito dedicato all'esito referendario, 22.10.2013, San Marino TV, https:/www.sanmarinortv.sm/news/politica-c2/consiglio-dibattito-dedicato-esito-referendario-a9378, 8.09.2021.

Decreto del 24 april 2003 n. 50 - Inammissibilita' di referendum propositivo (2003).

${ }^{18}$ So far, however, this has mainly concerned the deepening and expansion of European integration, and not the initial phase of European integration (Parol, 2021, p. 39).

19 F. Mendez draws attention to the uniqueness of the 2013 vote, pointing out that among the "EU" referendums we can distinguish: member referendums (on accession to the EU); revision referendums (on treaty changes); referendums on EU policy (such as the referendum in Greece in 2015) and the third-country referendum (which could be translated as a referendum of a third country), an example of which, according to the author, is the Sammarinese referendum of 2013 (cf. Mendez, 2020, pp. 60-61).

${ }^{20}$ Early elections are the rule there, and elections on time are the exception. 
Guicciardi E. (2013), San Marino: Thanks but no thanks, EU accession!, 21.10.2013, European Public Affairs, http://www.europeanpublicaffairs.eu/san-marino-thanks-but-no-thanks-eu-accession/, 13.11.2020.

Il Pdcs sull'esito della tornata referendaria, 21.10.2013, Libertas.sm, http://www.libertas.sm/cont/comunicato/il-pdcs-sull-esito-della-tornata-referendaria/84581/1.html, 07.09.2021.

Istanza d'Arengo n.25 del 7 aprile 2019 - affinché sia indetto un referendum per l'ingresso nella Comunità Economica Europea (2019).

Istanza d'Arengo n.4 - Cittadini Sammarinesi perché il Consiglio Grande e Generale impegni il Governo a presentare formale domanda di adesione della Repubblica di San Marino all'Unione Europea (2011).

Koźbiał K. (2012), Europejskie mikropaństwa w procesie integracji europejskiej. Przykład Liechtensteinu, in: Hereditas Mercaturae. Księga pamiatkowa dedykowana świętej pamięci profesorowi Stanisławowi Miklaszewskiemu, eds. P. Czubik, Z. Mach, Kraków.

Kużelewska E. (2019), Same-Sex Marriage-A Happy End Story? The Effectiveness of Referendum on Same-Sex Marriage, „Białostockie Studia Prawnicze”, no. 24, pp. 13-27.

Legge 5 dicembre 2011 n.188 - Riforma della struttura e del modello organizzativo dell'Amministrazione Pubblica (2011).

Łukaszewski M. (2018), Arengo, obywatelska inicjatywa ustawodawcza. Instancja Arengo i referendum - formy demokracji bezpośredniej w San Marino na tle rozwiąań konstytucyjnych Włoch, in: Uwarunkowania demokracji bezpośredniej we wspótczesnej Europie, eds. M. Musiał-Karg, A. Stelmach, Poznań.

Łukaszewski M. (2019), When the People's Needs Are Not Listened to: Istanza d'Arengo on the Background of Other Forms of Direct Democracy in San Marino, "Białostockie Studia Prawnicze", vol. 24

Mendez F. (2020), A Paradigm Shift in National Referendums on Europe, in: How Referendums Challenge European Democracy: Brexit and Beyond, ed. R. Rose, Cham.

Musiał-Karg M. (2017), Referendum jako instytucja wplywania na przyszłość zjednoczonej Europy. Brexit a ksztalt Unii Europejskiej, „Rocznik Integracji Europejskiej”, no. 11, pp. 225-240.

Ordine del Giorno presentato dai Gruppi Consiliari di maggioranza che impegna il Governo ad aprire un negoziato per una maggiore integrazione della Repubblica di San Marino con l'Unione Europea; seduta del 15 dicembre 2010 (2010).

Ordine del Giorno presentato dai Gruppi Consiliari di maggioranza affinché il governo sia impegnato a: - proseguire le verifiche riguardo la capacità amministrativa funzionale all'acquis dell'Unione Europea, predisponendo apposito piano d'azione - perseguire l'obiettivo dell'integrazione nell'U.E. della Repubblica tramite apposito iter di assunzione della normativa comunitaria nell'ambito della legislazione nazionale - riferire semestralmente - al consiglio grande e generale - sul relativo stato di attuazione (2013).

Ordine del Giorno presentato dal Gruppo Consiliare del PSD conclusivo del dibattito sul Rapporto del Consiglio dell'Unione Europea sulle relazioni dell'Unione Europea con la Repubblica di San Marino, il Principato di Andorra e il Principato di Monaco (2011).

Parol A. (2021), Dychotomiczny podziat referendów dotyczacych integracji europejskiej. Europejskie referenda bottom-up, „Przegląd Sejmowy”, nr 3(164).

Per San Marino: Una vittoriosa sconfitta, 21.10.2013, Libertas.sm, http://www.libertas.sm/cont/comunicato/per-san-marino-una-vittoriosa-sconfitta/84570/1.html, 03.09.2021.

Rapporto definitivo e consolidato del Gruppo tecnico per la valutazione di nuove modalità di integrazione con l'Unione Europea, presentato nella sessione di dicembre del 2010 del Consiglio Grande e Generale della Repubblica di San Marino (2010).

Referendum, Noi Sammarinesi: San Marino non dice no all'Europa, 21.10.2013, Libertas.sm, http://www.libertas.sm/cont/comunicato/referendum-noi-sammarinesi-san-marino-non-dice-no-all-europa/84575/1.html, 24.08.2021. 
Rete: qualche osservazione dopo il referendum, 21.10.2013, Libertas.sm, http://www.libertas.sm/cont/ comunicato/rete-qualche-osservazione-dopo-il-referendum/84565/1.html, 07.09.2021.

San Marino - Unione Europea. Antonella Mularoni ha incontrato Jose' Barroso, Libertas.sm, 11.07.2012, http://www.libertas.sm/cont/news/san-marino-unione-europea-antonella-mularoni-ha-incontrato-jose-barroso/64549/1.html, 13.10.2020.

San Marino 3.0. Ok referendum Europa! Ora la prima cosa da fare è cacciare la Dirigenza di Banca Centrale!, 22.10.2013, Griornale.sm, https:/giornalesm.com/san-marino-3-0-ok-referendum-europa-ora-la-prima-cosa-da-fare-e-cacciare-la-dirigenza-di-banca-centrale-19293/, 06.09.2021.

San Marino Oggi. I commenti post-referendum, 21.10.2013, Libertas.sm, http://www.libertas.sm/cont/ news/san-marino-oggi-i-commenti-post-referendum/84544/1.html, 07.09.2021.

San Marino. Affondato il referendum Europa, ma il Psd non si arrende: chi non ha votato non voleva dire 'no', 22.10.2013, Griornale.sm, https://giornalesm.com/san-marino-affondato-il-referendum-europa-ma-il-psd-non-si-arrende-chi-non-ha-votato-non-voleva-dire-no-20954/, 06.09.2021.

San Marino. Flop del referendum Europa, Rete: "Spiace che il comitato promotore non voglia prendere atto della sovranità delle decisioni popolari”, 21.10.2013, Griornale.sm, https://giornalesm. $\mathrm{com} /$ san-marino-flop-del-referendum-europa-rete-spiace-che-il-comitato-promotore-non-voglia-prendere-atto-della-sovranita-delle-decisioni-popolari-87364/, 06.09.2021.

San Marino. Valentini (Esteri) ieri a colloquio con Schulz, Presidente Parlamento Europeo, Libertas. sm, 21.08.2013, http://www.libertas.sm/cont/news/san-marino-valentini-esteri-ieri-a-colloquio-con-schulz-presidente-parlamento-europeo/81934/1.html, 13.10.2020.

San Marino: richiesta formale di adesione a UE, 08.02.2011, altarimini.it, https://www.altarimini.it/ san_marino_richiesta_formale_di_adesione_a_ue-33436.php, 09.09.2021.

Statement by Herman Van Rompuy President of the European Council following his meeting with Antonella Mularoni Secretary of State for Foreign and Political Affairs in San Marino (2011), Brussels, 6 September 2011, EUCO 65/11, Presse 297, PR PCE 38, http://www.consilium.europa.eu/uedocs/cms_data/docs/pressdata/en/ec/124509.pdf, 13.10.2020.

Upr: risultato del Referendum, 21.10.2013, Libertas.sm, http://www.libertas.sm/cont/comunicato/ upr-risultato-del-referendum/84566/1.html, 05.09.2021.

\section{Parlament-rząd-obywatele. Miejsce instytucji demokracji bezpośredniej w dyskusji nad ksztaltem stosunków San Marino-Unia Europejska w kontekście referendum z 2013 roku}

\section{Streszczenie}

Przedmiotem artykułu jest kwestia wykorzystania instytucji demokracji bezpośredniej w procesie kształtowania kierunków bardzo konkretnego elementu polityki zagranicznej - relacji z Unią Europejską, którego San Marino nie jest członkiem. O ile większość referendów związanych z Unią Europejską dotyczy akcesji państw do tej organizacji, to głosowanie z 2013 roku miało nieco inny charakter. Dlatego autor podejmuje się próby wskazania w jaki sposób wykorzystanie przez obywateli instrumentów demokracji bezpośredniej stojących niejako w kontrze do instytucji demokracji pośredniej (parlamentu i zależnego od niego rządu) może przyczynić się do podejmowania przez decydentów pożądanych przez obywateli decyzji politycznych nawet w tak z pozoru raczej nietypowych (poza wspomnianymi referendami akcesyjnymi) dla demokracji bezpośredniej sferach jak kierunki polityki zagranicznej.

Słowa kluczowe: referendum, San Marino, integracja europejska 
